\title{
New distribution records of cave-dwelling gekkonid lizards (Sauria, Gekkonidae and Phyllodactylidae) in the Zagros Mountains of Iran
}

\author{
Somayeh Esmaeili-Rineh', Vahid Akmali', Farajollah Fathipour', \\ Nastaran Heidari², Nasrullah Rastegar-Pouyani'
}

I Department of Biology, Faculty of Sciences, Razi University, 6714967346, Kermanshah, Iran 2 Department of Animal Biology, Faculty of Biological Science, Kharazmi University. Tehran, Iran

Corresponding author: Vahid Akmali (v_akmali@razi.ac.ir)

Academic editor: O. Moldovan | Received 19 February 2016 | Accepted 23 May 2016 | Published 10 June 2016

http://zoobank.org/1FBFF48E-EA5D-4051-907E-EB5803835F79

Citation: Esmaeili-Rineh S, Akmali V, FathipourF, Heidari N, Rastegar-Pouyani N (2016) New distribution records of cave-dwelling Gekkonid Lizards (Sauria, Gekkonidae and Phyllodactylidae) in the Zagros Mountains of Iran. Subterranean Biology 18: 39-47. doi: 10.3897/subtbiol.18.8185

\begin{abstract}
The distribution of cave-dwelling lizards of the families Gekkonidae and Phylodactylidae (Sauria) was investigated in the Zagros Mountains of Iran. Obtained information includes new distribution records of species from 15 caves. The caves are Bendireh, Taigeh, Ban, Zarrinabad, Ghadah, Kulkani, and Darhamreh in Ilam Province, Pelazh, Gavbar and Asmari in Khuzestan Province, Tadovan, Manian and Sangeshkan in Fars Province and Dalaki and Khesht in Bushehr Province. In this study, five species belonging to the Gekkonidae and Phylodactylidae families were recorded including: Asaccus elisae, Asaccus nasrullahi, Hemidactylus persicus, Cyrtopodion scabrum, and Cyrtopodion gastrophole.
\end{abstract}

\section{Keywords}

Cave-dwelling lizards, Gekkonidae and Phylodactylidae, Zagros Mountains, Western Iran 


\section{Introduction}

In recent years, there has been a rapid increase in information available on the fauna of caves (Chapman 1983, Culver and Sket 2000, Bauer et al. 2002, Ngo et al. 2008, Afrasiab 2011). There is only one record for cave dwelling lizards, Asaccus kermanshahensis Rastegar-Pouyani, 1996, in Iran which, so far, has not been reported from other habitats, although the diversity of caves fauna in Iran is not well known (Esmaeili-Rineh and Sari 2013). The northern and western borders of the country are bounded by two large mountain ranges, the Elburz and Zagros, respectively. These two mountain ranges have played an important role in shaping the past and present distribution patterns of various Agamid, Scincid and Gekkonid taxa (Macey et al. 2000, Torki et al. 2010, Afrasiab et al. 2013). The Zagros Mountains include a series of parallel ridges interspersed with plains that bisect the country from northwest to southeast. The $\mathrm{Za}-$ gros Mountains represent 55\% of all karstic-carbonate formations in Iran, and more than 250 caves, most dry, are known from this region (Raeisi 2004). A number of species of animals live permanently or temporarily in these caves, including bats, blind crustacean, blind fishes and arthropods in deeper part or lizards, snakes, and birds near the entrance (Akmali et al. 2011, Esmaeili-Rineh and Sari 2013, Sharifi et al. 2014).

Although there are no obligate cave-dwelling (i.e., troglobionts) reptiles, caves are used on a temporary to long-term basis by several snakes and lizards around the globe (Afrasiab 2011). Some colubrid snakes hunt bats at cave entrances or enter caves to hunt roosting bats (Akmali et al. 2011, Sharifi et al. 2014). Among lizards, geckos are considered the most common cave-dwelling lizards (Culver 2000, Bauer et al. 2002). There are nearly 50 described species of lizards belonging to 10 families that occur in the Zagros Mountains (Anderson 1999). Gekkonidae is the largest family of geckos consisting of over 950 described species belonging to 51 genera (Uetz and Hošek 2015). Gekkonids along with Lacertid lizards are among the most diverse family of lizards in the Zagros Mountains (Anderson 1999).

In this study, we describe the lizard fauna of caves in the Zagros Mountains. The purpose of this study is to identify cave dwelling lizard's species as important elements of life in caves of central and southern parts of the Zagros Mountains.

\section{Methods}

We surveyed 15 caves for lizards in the southern, southwestern and western parts of Iran in Bushehr, Fars, Ilam and Khuzestan provinces, which is the primary region with caves and karst development in the Zagros Mountains (Figures 1 and 2; Table 1). Sampling of lizards was done by using long pans and special bags, and the latitude and longitude of caves were recorded using a Garmin GPS unit (GPSMAP 60CSx; Garmin International, New York, USA). Captured lizards were photographed and identified in the field. 


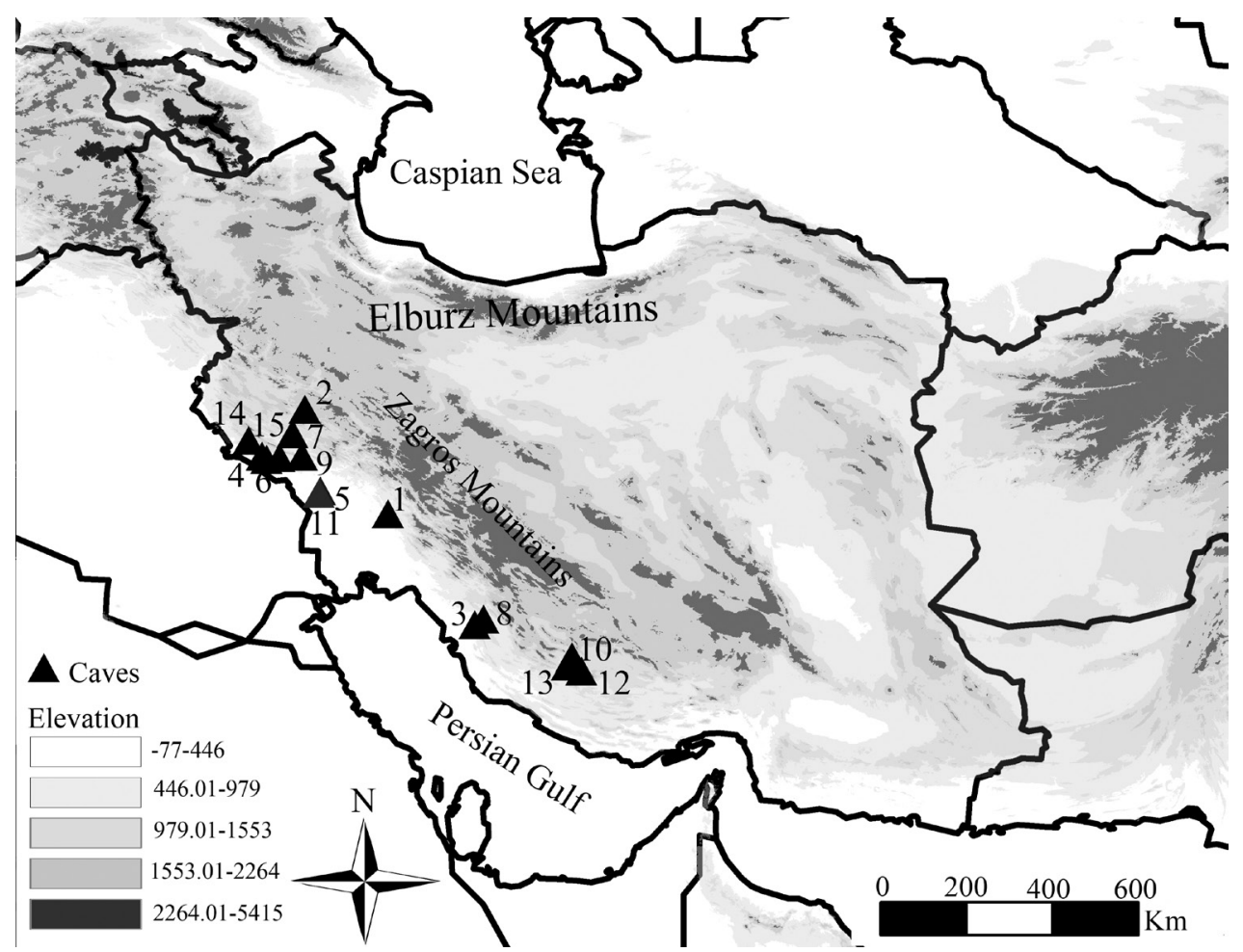

Figure I. Location of the visited caves in the Zagros Mountains. (Numbers show caves: I Asmari 2 Bendirh 3 Dalaki 4 Darhamreh 5 Gavbar 6 Ghadah 7 Ban 8 Khesht 9 Kulkani 10 Manian II Pelazh I 2 Sangeshkan 13 Tadovan 14 Taigeh 15 Zarinabad).

\section{Results}

Five species of Gekkonid lizards belonging to Asaccus, Hemidactylus and Cyrtopodion genera were collected from the 15 caves throughout the Zagros Mountains in western and southwestern Iran (Table 1 and Figure 3A-F) as follow.

\section{Cyrtopodion scabrum (Heyden, 1827)}

Figure 3A

Keeled rock gecko, rough-tailed gecko and rough thin-toed gecko

Remarks. Mean snout-vent length $38.9 \mathrm{~mm}$ and tail $49.2 \mathrm{~mm}$.

This species has a wide distribution range from Egypt through southwest Asia to northwestern India (Anderson 1999). It is mostly distributed in western Iran, rarely found out of residential places, and it is the most common house gecko in western 

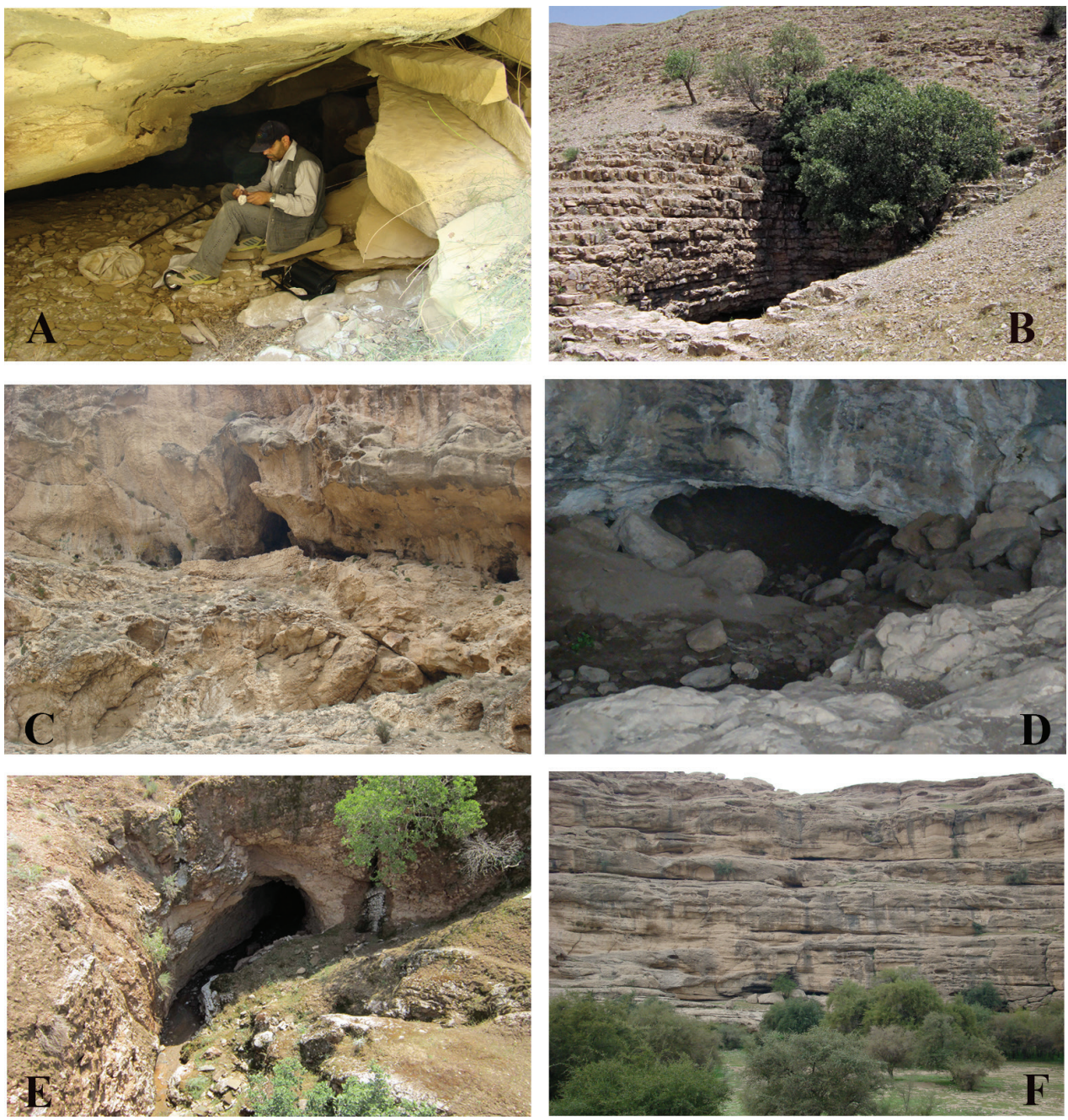

Figure 2. Some of the caves visited in the studied area. For more details and coordinations refer to Table 1. Dalaki (A), Taigeh (B), Tadovan (C), Manian (D), Zarrinabad (E) and Gavbar (F).

Iran (Anderson 1999). Caves are not the common habitat for this gecko, but we could observe this species at two caves in Ilam and Fars provinces (Table 1). Darhamreh cave is limestone cave with a small and bright entrance. Internal environment of this cave is completely dry and there is no water. The other cave (Sangeshkan) is a system of artificial underground spaces (disused sandstone mines) in a hill at the southern margin of Jahrom town (Fars province). The cave consists of some chambers with broken and fallen ceilings, creating a number of smaller spaces, fissures and crevices, well useful as roosts. 
Table I. Coordinates, altitudes, length (m) and entrance size of caves and list of the Gekkonid lizards observed and collected in this study.

\begin{tabular}{|c|c|c|c|c|c|c|c|c|}
\hline @્心 & . & $\begin{array}{l}8 \\
0 \\
0 \\
0 \\
0\end{array}$ & 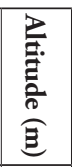 & 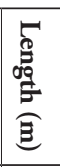 & ) & $\begin{array}{l}\text { क्ष } \\
\text { గ్రై. }\end{array}$ & 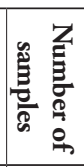 & 胥 \\
\hline Asmari & Khuzestan & $31^{\circ} 46^{\prime} \mathrm{N} ; 49^{\circ} 30^{\prime} \mathrm{E}$ & 434 & - & Small & Asaccus elisae & 4 & Phyllodactylidae \\
\hline Bendireh & Ilam & $32^{\circ} 58^{\prime} \mathrm{N} ; 47^{\circ} 46^{\prime} \mathrm{E}$ & 413 & 40 & Large & Asaccus elisae & 4 & Phyllodactylidae \\
\hline Darhamreh & Ilam & $32^{\circ} 55^{\prime} \mathrm{N} ; 46^{\circ} 58^{\prime} \mathrm{E}$ & 615 & 20 & Small & Asaccus elisae & 7 & Phyllodactylidae \\
\hline Gavbar & Khuzestan & $32^{\circ} 15^{\prime} \mathrm{N} ; 48^{\circ} 05^{\prime} \mathrm{E}$ & 90 & 47 & Small & Asaccus elisae & 3 & Phyllodactylidae \\
\hline Ghadah & Ilam & $32^{\circ} 57^{\prime} \mathrm{N} ; 47^{\circ} 14^{\prime} \mathrm{E}$ & 1029 & 220 & Large & Asaccus elisae & 5 & Phyllodactylidae \\
\hline Khesht & Bushehr & $29^{\circ} 34^{\prime} \mathrm{N} ; 51^{\circ} 30^{\prime} \mathrm{E}$ & 416 & 15 & Large & Asaccus elisae & 8 & Phyllodactylidae \\
\hline Zarrinabad & Ilam & $32^{\circ} 59^{\prime} \mathrm{N} ; 46^{\circ} 52^{\prime} \mathrm{E}$ & 796 & 100 & Large & Asaccus elisae & 3 & Phyllodactylidae \\
\hline Kulkani & Ilam & $32^{\circ} 59^{\prime} \mathrm{N} ; 47^{\circ} 42^{\prime} \mathrm{E}$ & 512 & 70 & Large & Asaccus nasrullahi & 2 & Phyllodactylidae \\
\hline Darhamreh & Ilam & $32^{\circ} 55^{\prime} \mathrm{N} ; 46^{\circ} 58^{\prime} \mathrm{E}$ & 615 & 20 & Small & Cyrtopodion scabrum & 5 & Gekkonidae \\
\hline Sangeshkan & Fars & $28^{\circ} 29^{\prime} \mathrm{N} ; 53^{\circ} 33^{\prime} \mathrm{E}$ & 1091 & 300 & Large & Cyrtopodion scabrum & 4 & Gekkonidae \\
\hline Dalaki & Bushehr & $29^{\circ} 27^{\prime} \mathrm{N} ; 51^{\circ} 19^{\prime} \mathrm{E}$ & 259 & 20 & Small & Cyrtopodion gastrophole & 3 & Gekkonidae \\
\hline Ban & Ilam & $33^{\circ} 27^{\prime} \mathrm{N} ; 47^{\circ} 30^{\prime} \mathrm{E}$ & 1391 & 90 & Large & Hemidactylus persicus & 1 & Gekkonidae \\
\hline Manian & Fars & $28^{\circ} 35^{\prime} \mathrm{N} ; 53^{\circ} 15^{\prime} \mathrm{E}$ & 1077 & 40 & Large & Hemidactylus persicus & 8 & Gekkonidae \\
\hline Pelazh & Khuzestan & $32^{\circ} 12^{\prime} \mathrm{N} ; 48^{\circ} 03^{\prime} \mathrm{E}$ & 110 & 36 & Large & Hemidactylus persicus & 5 & Gekkonidae \\
\hline Sangeshkan & Fars & $28^{\circ} 29^{\prime} \mathrm{N} ; 53^{\circ} 33^{\prime} \mathrm{E}$ & 1091 & 300 & Large & Hemidactylus persicus & 4 & Gekkonidae \\
\hline Tadovan & Fars & $28^{\circ} 47^{\prime} \mathrm{N} ; 53^{\circ} 21^{\prime} \mathrm{E}$ & 1200 & 300 & Large & Hemidactylus persicus & 6 & Gekkonidae \\
\hline Taigeh & Ilam & $33^{\circ} 19^{\prime} \mathrm{N} ; 46^{\circ} 35^{\prime} \mathrm{E}$ & 1204 & 25 & Small & Hemidactylus persicus & 2 & Gekkonidae \\
\hline
\end{tabular}

\section{Cyrtopodion gastrophole (Werner, 1917)}

Figure 3B

Werner's bent-toed gecko, Persian Spider-gecko

Remarks. Mean snout-vent length $44.8 \mathrm{~mm}$, tail $54.5 \mathrm{~mm}$.

This species is an endemic species for Iran, known only from its type locality, the Fars province. But we collected this species in a cave in Bushehr province. We collected this species inside Dalaki cave, in humid and cool places used as a shelter for physiological thermoregulation during mid-day hours. Usually active at night but in the middle of the day it was found in shaded areas and feed on Lepidoptera insects.

\section{Asaccus elisae (Werner, 1895)}

Figure 3C, D

Werner's leaf-toed gecko

Remarks. Mean snout-vent length $42.5 \mathrm{~mm}$, tail $29.8 \mathrm{~mm}$.

This species was mostly observed and collected in caves in Iran (Anderson 1999). Other researchers (Weber 1960, Wettstein and Löffler 1951) reported it as a house gecko in Iraq on the Mesopotamian plain. This species was collected in seven caves 

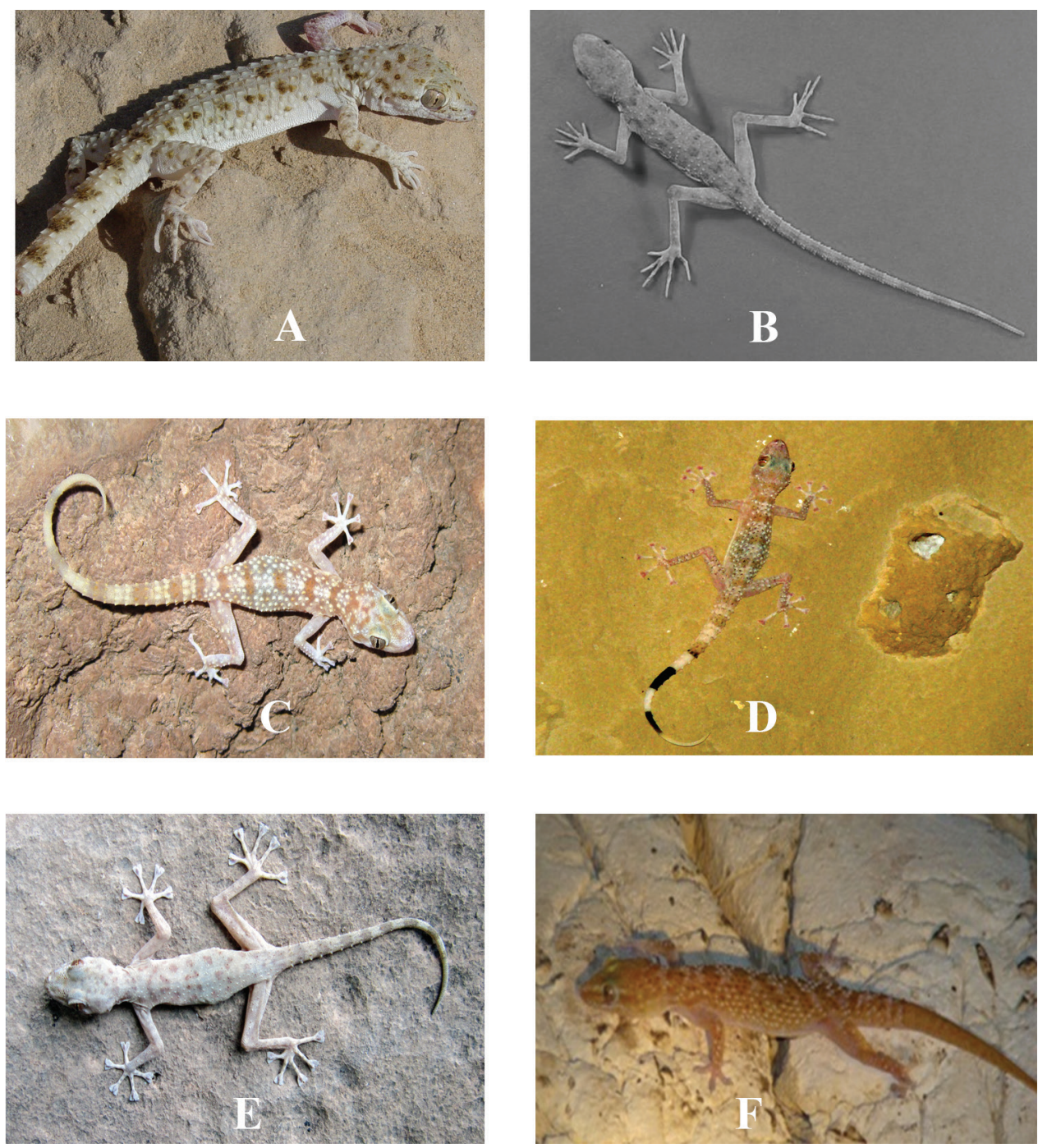

Figure 3. The collected species in this study in the caves located in Table 1. Cyrtopodion scabrum (A), Cyrtopodion gastrophole (B), Asaccus elisae (C, D), Asaccus nasrullahi (E), Hemidactylus persicus (F).

(Table 1). Six of them are limestone caves with dry and bright entrances. One of these cave (Zarinabad) have gypsum structure and at the time of the year there is running water inside it. Due to its tunnel-like shape air flows through it.

\section{Asaccus nasrullabi Werner, 2006}

Figure 3E

Nasrullah's leaf-toed gecko

Remarks. Mean snout-vent length $70 \mathrm{~mm}$, tail $66.8 \mathrm{~mm}$. 
The species is distributed in parts of the West and Southwest of the Zagros Mountains, mainly in Loristan province. In this study we report a new record of this taxon from Kulkani cave in Ilam province. Kulkani is limestone cave with large and bright entrance. The cave can be divided into two parts. The first part is dry and bright where specimens were found in it. The second part is smaller and dark with little humidity.

\section{Hemidactylus persicus Anderson, 1872}

Figure 3F

Persian gecko

Remarks. Mean snout-vent length $53.3 \mathrm{~mm}$, tail $62.9 \mathrm{~mm}$.

The species is widely distributed from coastal Arabia north to southern Iran and Iraq, east to Sind Waziristan, Pakistan (Anderson 1999). In Iran it is known from Khuzestan, Fars, Kerman, and Baluchistan Provinces. We collected this gecko in six caves (Table 1). All of these caves are located in different parts of the Zagros Mountains and are formed in limestone. The caves are almost similar in terms of habitat conditions such as moisture content, hydrology, entrance size and brightness. One of these caves is Tadovan located at a height of 1200 meter above the sea level. This cave is large and complex with a large entrance within a rocky overhang and is situated in a steep cliff on the left, eastern side of the Ghare-Aghaj river valley. The cave is a series of well passable corridors and domes of different width (ca. 1-5 m) and height (ca. 2-7 m). Immediately inside the entrance is a large pit of about $6 \mathrm{~m}$ in depth. After the pit, in the twilight zone, is a large gallery with $36 \%$ humidity and $30^{\circ} \mathrm{C}$ temperature. Hemidactylus persicus was found in this gallery which has the lowest humidity $(36 \%)$ compared to other galleries in which their humidity ranges from $45 \%$ to $97 \%$. This lizard was not found in other parts of the cave with different humidity.

\section{Discussion}

We visited 15 caves and recorded five species of Gekkonid lizards, Asaccus elisae, Asaccus nasrullahi, Hemidactylus persicus, Cyrtopodion scabrum, and Cyrtopodion gastrophole. Of the above-mentioned recorded species, only Asaccus elisae was previously reported by Anderson (1999) from caves and non-caves habitats. Anderson (1999) found it in a cave in Fars Province and in Lorestan Province under a large flake of exfoliated sandstone on a cliff face above a stream. This species is sympatric with Cyrtopodion scabrum, Hemidactylus persicus, and $H$. flaviviridis in western and southwestern regions of Iran (Parsa et al. 2009).

Geckos are chiefly surface active animals but there are great varieties of Gekkonid lizards adapted to live in darkness situations (such as caves) with some pre-adaptations for occupying cave environments and deep rock grooves such as long snout, reduced keeled tubercles, absence of caudal tubercles, all for crawling in rock cracks inside the caves, adhesive paddles, and slender limbs for climbing (Bauer et al. 2002). Cyrtopo- 
dion scabrum is mostly known as a house gecko and there is no record of this species in other habitats as was sustained by Anderson (1999). We observed this species in two caves, hence extended the knowledge of habitat characteristics of this species. Although many of collected and identified lizard species used to caves as resting areas during the day and were observed around the caves in the rocky habitats, none of them is a true cave-dwelling species in Iran.

\section{Acknowledgments}

We thank the staff of Cultural Heritage and Tourism and Department of Environment for providing information about caves. We kindly thank Hiva Faizi who carefully read this manuscript and provided useful modifications in early version of the manuscript. We thank the anonymous reviewer and the editor for corrections and comments on the previous version of the manuscript.

\section{References}

Afrasiab Lahony SR, Mohammad KM, Ali HH, Al-Moussawi AA, Abd Al-Rasul MS (2013) Fauna and flora of Hawraman mountain (part one) Hawraman lowest zone, Kurdistan province north east of Iraq. Bulletin of the Iraq Natural History Museum 12: 7-34.

Afrasiab Lahony SR (2011) Cave dwelling animals in Iraq Part 2: Systematic notes on the nuthatch of the family sittidae (Aves: passeriformes) in Iraq with adding some important knowledge to the nest building of Sitta tephronota sharpe, from besan vale hawraman slope. Iraqi Kurdistan. Bulletin of the Iraq Natural History Museum 11: 17-24.

Akmali V, Sharifi M, Esmaeili-Rineh S (2011) Corrective measures in management of bat habitats in the central Zagros. In: Zehzad B (Ed.) Proceedings of the First National Seminar on Threats of Biological Diversity Resources and Root Causes of Biodiversity Lose in the Central Zagros (February 16-17, Esfahan University of Technology), 207-212. [In Farsi, with a summary in English]

Anderson SC (1999) The lizards of Iran. Society for the Study of Amphibians and Reptiles, Oxford University Press, Ohio, $442 \mathrm{pp}$.

Bauer AM, Pauwels OSG, Chanhome L (2002) A new species of Cave-dwelling Cyrtodactylus (Squamata: Gekkonidae) from Thailand. The Natural History Journal of Chulalongkorn University 2: 19-29.

Chapman J (1983) Species diversity in a tropical cave ecosystem. Proceedings of the University of Bristol Speleological Society 16: 201-213.

Culver DC, Sket B (2000) Hotspots of subterranean biodiversity in caves and wells. Journal of Cave and Karst Studies 62: 11-17.

Esmaeili-Rineh S, Sari A (2013) Two new species of Niphargus Schiödte, 1849 (Crustacea: Amphipoda: Niphargidae) from two caves in Iran. Journal of Natural History 47: 2649-2669. doi: $10.1080 / 00222933.2013 .802041$ 
Macey R, Schulte J, Ananjeva N, Larson A, Rastegar-Pouyani N, Shammakov S, Papenfuss T (2000) Phylogenetic relationships among Agamid Lizards of the Laudakia caucasia complex: Testing hypotheses of biogeographic fragmentation and an area cladogram for the Iranian Plateau. Molecular Phylogenetics and Evolution 10: 118-131. doi: 10.1006/ mpev.1997.0478

Ngo TV, Grismer LL, Grismer JL (2008) A new endemic cave dwelling species of Cyrtodactylus Gray, 1827 (Squamata: Gekkonidae) in Kien Giang Biosphere Reserve, Southwestern Vietnam. Zootaxa 1967: 53-62.

Parsa H, Oraie H, Khosravani A, Rastegar-Pouyani N (2009) Systematics and distribution of the Iranian Plateau Leaf-toed Geckos of the Genus Asaccus (Sauria: Gekkonidae). Iranian Journal of Animal Biosystematics 5: 43-55.

Raeisi E (2004) Iran cave and karst. In: Gunn J (Ed.) Encyclopedia of cave and karst. Fitzroy Dearborn, New York, 460-461.

Rastegar-Pouyani N (1996) A new species of Asaccus (Sauria: Gekkonidae) from the Zagros Mountains, Kermanshah Province, Western Iran. Russian Journal of Herpetology 3: 11-17.

Sharif Khan M (1999) Herpetology of habitat types of Pakistan. Pakistan Journal of Zoology 31: 275-289.

Sharifi M, Akmali V, Fathinia B, Vaissi S, Esmaieli-Rineh S (2014) Record of predation on the bat Rhinopoma microphyllum (Chiroptera: Rhinopomatidae) by Spalerosophis microlepis (Reptilia: Colubridae), in western Iran. Galemys 26: 114-118. doi: 10.7325/Galemys.2014.N6

Torki F, Heidari N, Sharif Khan M (2010) A Morphological and Ecological Study of Asaccus Nasrullahi Werner, 2006 (Reptilia: Phyllodactylidae), in Western Iran. Russian Journal of Herpetology 17: 195-201.

Uetz P, Hošek J (2015) The Reptile Database. http://www.reptile-database.org [accessed 6 October, 2015]

Weber NA (1960) Some Iraq amphibians and reptiles with notes on their food habits. Copeia 2: 153-154. doi: 10.2307/1440221

Wettstein O, Löffler H (1951) Ergebnisse der Österreichischen Iran-Expedition 1949/50 Amphibien und Reptilien. Sitzungsberichte der Akademie der Wissenschaften mathematisch-naturwissenschaftliche Klasse 160: 427-448. 